\title{
Vertical movements along the northwestern side of Messina straits, in the 1967-1970 period
}

\author{
V. Achilli ** - F. Broccio * - F. Mulargia *
}

Received on April 8th, 1982

\begin{abstract}
The results of a comparison of the spirit levelling data made by I.G.M. in 1967 and in 1970, are presented. An analysis of these data shows that the altitude variations of bench marks in the considered triennial period seem to originate from the collective rotation of an inclined plane, which intersects the geoid surface with an azimuth of $43^{\circ}$ to the North.

This is in accordance with the orientation of the fault pattern given by local geology.

The fact that the existing bench marks were sited along the coastline, and the lack of a comparison with data relative to motion on more compact geological structures, lead necessarily to provisional conclusions.
\end{abstract}

\section{RIASSUNTO}

Vengono riportati i risultati ottenuti da un confronto di livellazioni effettuate dall'I.G.M. dal 1967 al 1970 . Un'analisi di questi dati mostra che le variazioni di altezza dei caposaldi, nel triennio preso in esame, sembrano essere originate da una rotazione collettiva di un piano inclinato che interseca la superficie del geoide con un azimut di $43^{\circ} \mathrm{N}$. Ciò è in accordo con l'orientamento del modello di faglia dato dalla geologia locale. Il fatto che i caposaldi esistenti siano situati lungo una linea costiera e la mancanza di un confronto con i dati relativi al moto su strutture geologiche più compatte, porta necessariamente a conclusioni provvisorie.

* Istituto Geofisico e Geodetico, Università di Messina, Italy.

** Istituto Nazionale di Geofisica, Roma, Italy. 


\section{INTRODUCTION}

The Straits of Messina is one of the most important areas, from the geological point of view, of the whole Mediterranean. Disastrous earthquakes repeatedly occurred in this zone (Baratta, 1901), reaching a maximum on the 28th December 1908, with a magnitude 7.2 earthquake which completely destroyed the cities of Messina and Reggio Calabria and caused over 120,000 victims.

Considering just one of the relatively recent periods of strong seismic activity, i.e., the period beginning in 1783, which consisted of several events reaching a magnitude $M>7.0$, we can infer an alongated elliptical mesoseismic area, with major axis in the NE-SW direction (Baratta, 1901). This area extended its boundaries from Nicotera to the lower part of Aspromonte, while some of the following great shocks seem to have origin in the area of Messina Straits.

Because of the complex seismicity of the area, it is very difficult to estabilish precisely which are the seismogenetic structures, especially since for most of the events instrumental records are not available.

For the greatest earthquake in this area, the $28^{\text {th }}$ December 1908 one, some instrumental records are available.

Many researchers studied this earthquake (Schick, 1977), starting from the determination of focal parameters and concluded that it is related to the Sicilian and Calabrian tectonics structures, showing a clear correlation with a fault that starting from Comiso and passing through Etna and Messina, reaches S. Eufemia (see fig. 1).

The focal mechanism was found to be a normal fault with dipping of $70^{\circ}$ and azimuth aligned on a NE-SW direction. A mapping of the earthquakes recorded in the last two decades with epicenter in this area (see fig. 1), shows a clear correlation with the main tectonic alignments (Bottari, 1971), while the focal mechanisms of these events show a typical structure with normal and vertical faulting.

\section{Geological pattern of the Messina Straits Area}

The geological literature concerning Sicily and Calabria has, 


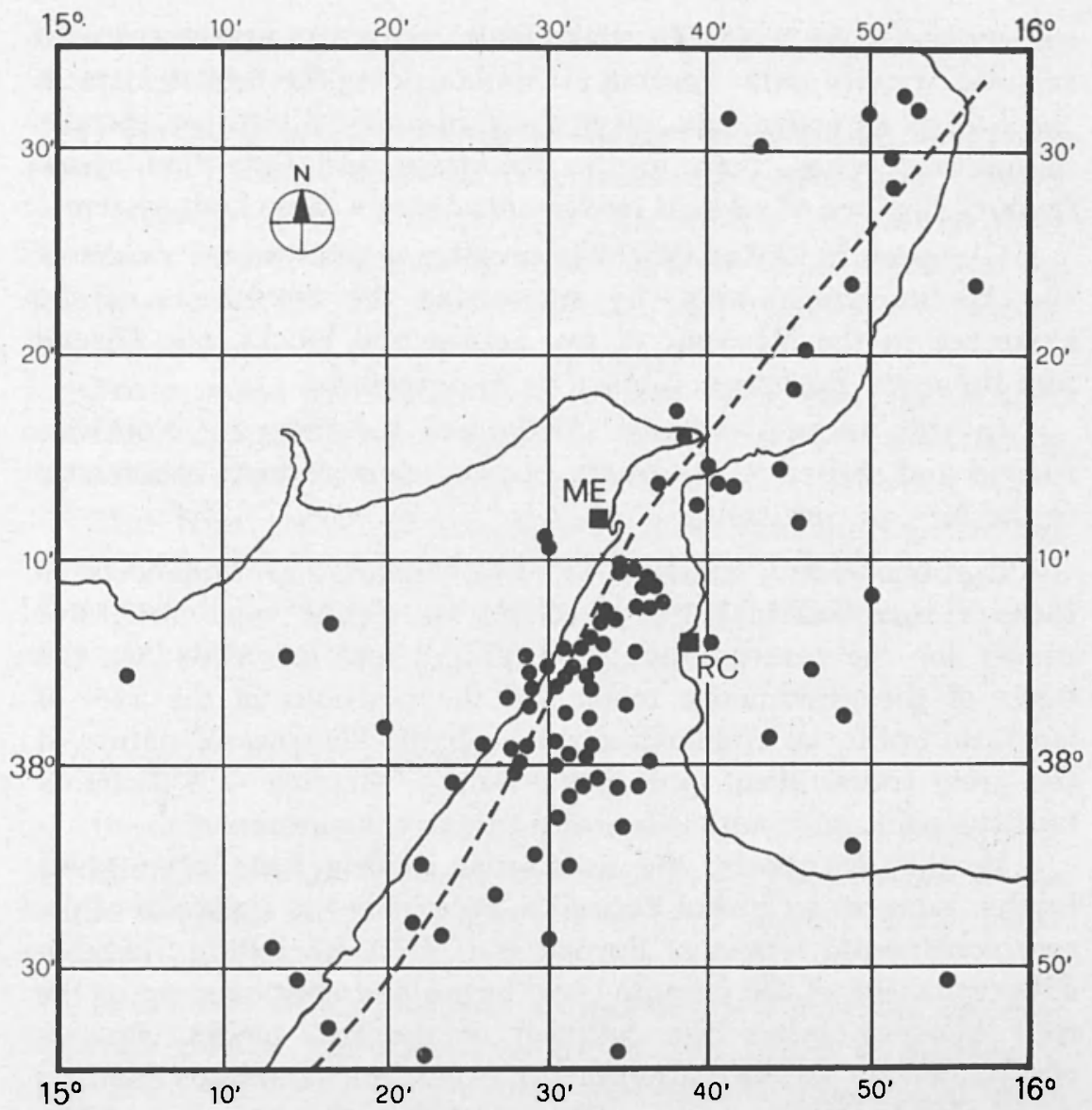

Fig. 1 - The epicenters of the seismic events instrumentally located in the Messina Straits area in the last 20 years (3).

on a variety of ways, supported an overthrust model which has taken the place (Bottari et al., 1975) of an earlier model based on total autochtony given by Cortese $(1882,1895)$; he was the first to recognize the Messina Straits fault and to set its origin in the lower to upper Pliocene.

Trevisan (1954) in a study of Quaternary tectonic movements, argues that these are the continuation of previous movements, and divides Sicily into four separate units, two of which are the Peloritani mountains and the Ragusa plateau, and the other two 
are separated by a NE-SW strike faults system in agreement with seismic activity data. Vecchia (1956) considers the fault system in the Straits as active, and, given the continuity of positive isostatic anomalous zones, both in the Peloritani and Calabrian areas, favours the idea of vertical movements along a large fault-system.

Glangeaud (1952a, 1952b) formulates a geodynamic model of the Mediterranean area, by supporting the hypothesis of the existence in the Mesozoic of two continental blocks, one African and the other European, divided by Sial-free-zone.

In this tectonic scheme, Sicily and Calabria are clockwise turned and shifted to the South, because they are part of the edge of the African continental block.

Ogniben $(1960,1966,1971,1973)$ taking up Limanowski's ideas (Limanowski, 1913), develops an Alpine type structural model for the centre-southern Apennines and for Sicily. On the basis of the gravimetric maps and the positions of the axes of isostatic uplift, he emphasizes the probable Pleistocenic nature of the great transcurrent fault of the Gela - Messina - S. Eufemia faulting zone, with anticlockwise transcurrent movement.

In the last years, the overthrust models have been given further support by global Tectonics. Following the approach of the two continental blocks of Europe and Africa (including Sicily), a subconduction of the oceanic crust began and continued up to the mid Miocene, when the collision of the two blocks was accompanied by the formation of the Peloritani mountains (Barberi et al., 1973; Bottari and Lo Giudice, 1975b; Caputo et al., 1970; Finetti and Morelli, 1972; Ritsema, 1971).

The subconduction under the Calabrian arc seems to be continuing still. The impact of the two continental blocks occurred in different phases, progressing in an anticlockwise direction from West to East. In the lower Miocene, Eastern Sicily was the limit between the zone of collision of the continental blocks and the zone of subconduction of the oceanic crust under the Calabrian arc. Sicily, therefore, was involved in a local distensive tectonics perpendicular to the direction of movements of the oceanic crust.

The origin of the Messina Abyssal Plain and the Messina Cone, which begins in the south of the Straits, is therefore based on this 
distensive tectonics, opening up in an anticlockwise direction (Bottari et al., 1975).

Interesting results are also available from geohpysical studies. From the oceanographic seismic reflection explorations (Finetti and Morelli, 1972), it seems that the African continental shelf continues beyond the Messina Straits and the Ionian Sea up to the southern edge of the Calabrian arc, and includes the Ragusa massif.

From these explorations it is also clear that the African continental shelf, due to a system of subvertical direct faults along the eastern edge of Sicily, is still subsiding under the Ionian Sea.

The first result of geodimetric measurements carried out between the two shores of the Messina Straits (Caputo et al., 1974) gives partial support to the idea of a northward drift of Sicily and an anticlockwise rotation of the Calabrian arc.

\section{GRound DEFormation MEASUREMENTS.}

In order to detect vertical movements, we can utilize the variation in altitude of fixed bench-marks, i.e. the variation of the height of fixed points on the ground with respect to the geoid surface.

Levelling, which consists of measuring differences in level between two or more fixed points, is well suited to investigate slow and continuous Earth crustal movements. In particular spirit levelling which is the most accurate levelling technique appears best suited to this purpose.

In the 1908, the "Istituto Geografico Militare" (I.G.M.), has been in charge of a precision geometric levelling in the region more violently shaken by 1908 earthquake. The results of this survey (Loperfido, 1909), are particularly interesting because the previous levelling survey had been completed just a few days before the disastrous event. Unfortunately the latter levelling could not be referred to the mean sea level because the earthquake damaged the tide gauges.

It was therefore referred to a reference plane which was assumed as fixed. 
The results of these levelling surveys were corrected in order to set the gravity level surface ortometric. Dynamic corrections were also made according the Clairaut's hypothesis, in order to take into account the defective parallelism of the level surface.

The results showed a maximum altitude variation of about 71 cm near the harbour office; variations of the same order of magnitude were found along the coastline. With regards to these maximum altitude variations, we must take into account superficial landslides which took place and were observed along the Messina coastline (Loperfido, 1909). After these, no further survey was made, until 1967-70 when I.G.M. carried out two high precision levelling surveys on two different lines but having some common path in the Messina Straits area (Istituto Geografico Militare, 1972). As it will be apparent in the following, the results of this survey are highly interesting.

\section{Discussion AND REsults.}

The analysis of the geological situation of the area, together at 1908 levelling data, shows a clear tendency to a sinking of the coast with respect to the Peloritani mountains. The same tendency is clearing apparent in the 1967-1970 data.

Fig. 2 shows the variations of the considered bench-marks difference of levels, in the 1967-70 period (table 1). We will see that furthermore these variations can be ascribed to the pivoting collective motion of a rigid plane sinking on one side.

If $\gamma$ indicates the reference plane respect to which we measure the variations of the altitude differences detected in the considered triennial period, let $\delta$ indicate the inclined plane produced by these variations, then elementary trigonometric considerations give an expression that relates the altitude variation of a benchmark as a function of $\alpha$ and $\varphi$, which are respectively the angle that $O A$ forms with the nodal line of the planes $\gamma$ and $\delta$, and the pivoting angle between the planes $\gamma$ and $\delta$ (see fig. 3).

In particular we have:

$$
\overline{A A^{\prime}}=\overline{O A} \operatorname{sen} \alpha \operatorname{sen} \varphi
$$


The difference in level between the 1967 and 1970 surveys. Note that there is a difference in the absolute reference level between them since the 1967 data were referred to the mareograph of Catania while the 1970 was referred to a trigonometric survey vertix of the I.G.M.

\begin{tabular}{|c|c|c|c|}
\hline BENCH-MARKS & SITING & 1967 & 1970 \\
\hline 1 & STAZIONE * & 5.0941 & 4.9359 \\
\hline 2 & DUOMO * & 7.1442 & 6.9896 \\
\hline 3 & MUNICIPIO * & 4.8920 & 4.7367 \\
\hline 4 & FIERA * & 2.9011 & 2.7460 \\
\hline 5 & V. LIBERTÀ & 3.5313 & 3.3797 \\
\hline 6 & PARADISO & 3.2126 & 3.0600 \\
\hline 7 & VILLA PRESTOPINO & 5.0064 & 4.8557 \\
\hline 8 & PORTICATELLO & 6.4898 & 6.3406 \\
\hline 9 & GROTTA & 4.3040 & 4.1547 \\
\hline 10 & GUARDIA & 6.1851 & 6.0326 \\
\hline 11 & S. AGATA & 11.4666 & 11.3138 \\
\hline 12 & LAVALLE & 2.0999 & 1.9468 \\
\hline 13 & ROCCA & 1.2737 & 1.1194 \\
\hline 14 & GRANATARI & 3.0473 & 2.8914 \\
\hline 15 & VILLA DE BERNARDIS & 6.3993 & 6.2456 \\
\hline 16 & MURO SOSTEGNO & 13.7917 & 13.6363 \\
\hline 17 & TIMPAZZI & 14.0933 & 13.9464 \\
\hline 18 & CASABIANCA GEMELLI & 16.3348 & 16.1817 \\
\hline 19 & CASABIANCA AGRILLO & 13.9021 & 13.7506 \\
\hline 20 & TONO & 13.2598 & 13.1065 \\
\hline
\end{tabular}

* In the metropolitan area of Messina. 


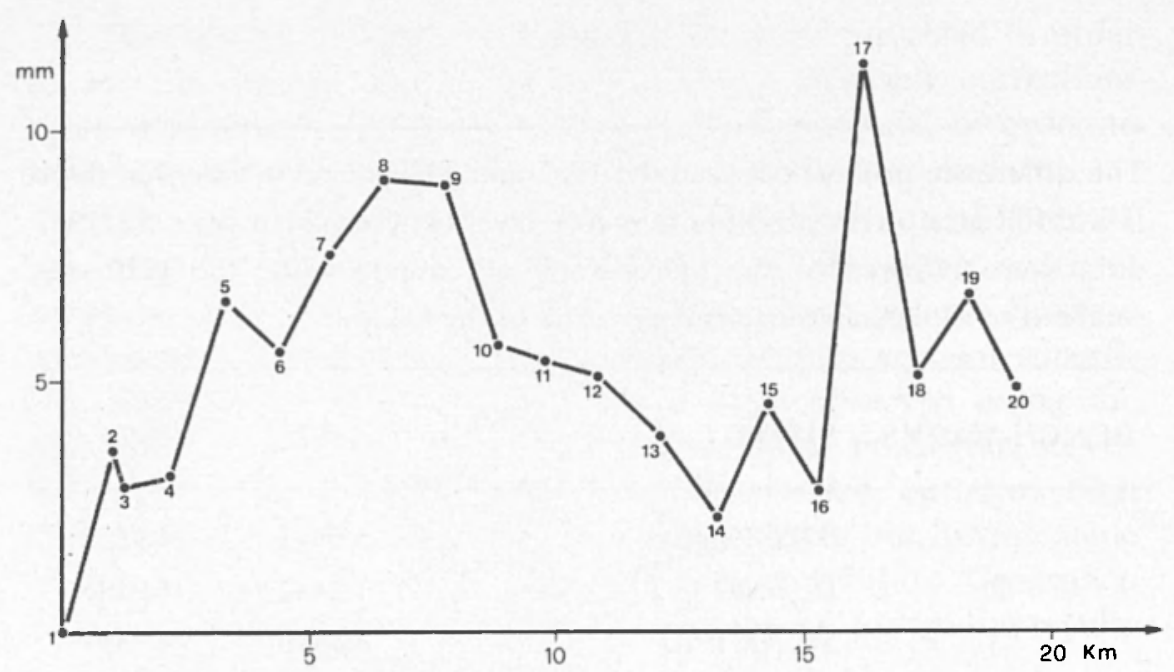

Fig. 2 - Differences in level from the 1967-70 I.G.M. survey. The differences in level are referred to bench-mark 1 (Stazione di Messina).

where $A A^{\prime}$ represents the difference of level variation in the considered interval of time, when we proceed from " $O$ " to " $A$ " bench-marks.

If $\beta$ is the azimuth with respect to the North of the line $\overline{E F}$, which is given from the intersection of $\gamma$ and $\delta$ planes, letting

$$
\text { sen }=K \text {, we have } \frac{\overline{A A^{\prime}}}{\overline{O A^{\prime}}}=\mathrm{K} \operatorname{sen}(\beta-\alpha) \text { and therefore }
$$

$$
\frac{\overline{A A^{\prime}}}{\overline{O A}}=K(\operatorname{sen} \beta \cos \alpha-\cos \beta \operatorname{sen} \alpha)
$$

We can easily solve equation [1] by taking couples of data and considering the azimuth of the connecting path together with their difference in level. 


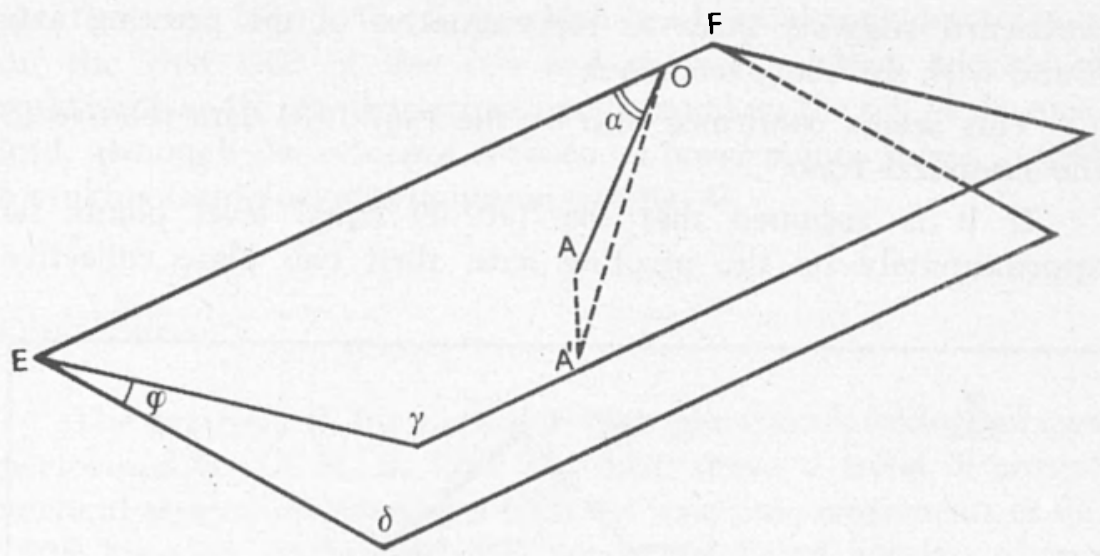

Fig. 3 - The pivoting plane geometry. $E F$ is the pivoting axis, while $\varphi$ is the pivoting angle. $0, A^{\prime}$ and $A$ are points on the ground (bench-marks) in the 1967 while $\alpha$ is the azimuth to plane strike.

If the solution of $\beta$, relative to different couples, are similar we will conclude that the measured vertical movements possibly occur as a consequence of the collective pivoting of an inclined plane, which intersect the reference plane with an azimuth $\beta$.

In order to caution from local level anomalies, we use the fact that some bench-marks are consecutively aligned and therefore by a linear regression we find the best fit line $\Delta h=\left(a_{2}+b_{i} D\right) \alpha=$ cost. The latter expression allows to calculate the kilometric trends, i.e. the difference in level per kilometer along the considered directions.

In our analysis we have considered six sets of equations obtaining six solutions for $\beta$ with average values of $\bar{\beta}=43^{\circ}$ and a percent standard deviation of $10,9 \%$.

A similar analysis performed for the 1907-1909 data shows two alignments (Scala - km 5 and Zona Militare - Castanea) which do not show variations in their differences of level. The difference in azimuth of these two alignments is very small (circa $10^{\circ}$ ) and the fact that differences in level are found going 
westward suggests them as representative of the pivoting axis found with the above technique.

This seems confirmed also by the $1967-1970$ data relative to the Timpazzi-Tono.

If it is assumed that the 1907-09 equal level points lie approximately on the pivoting axis, then two plate collective

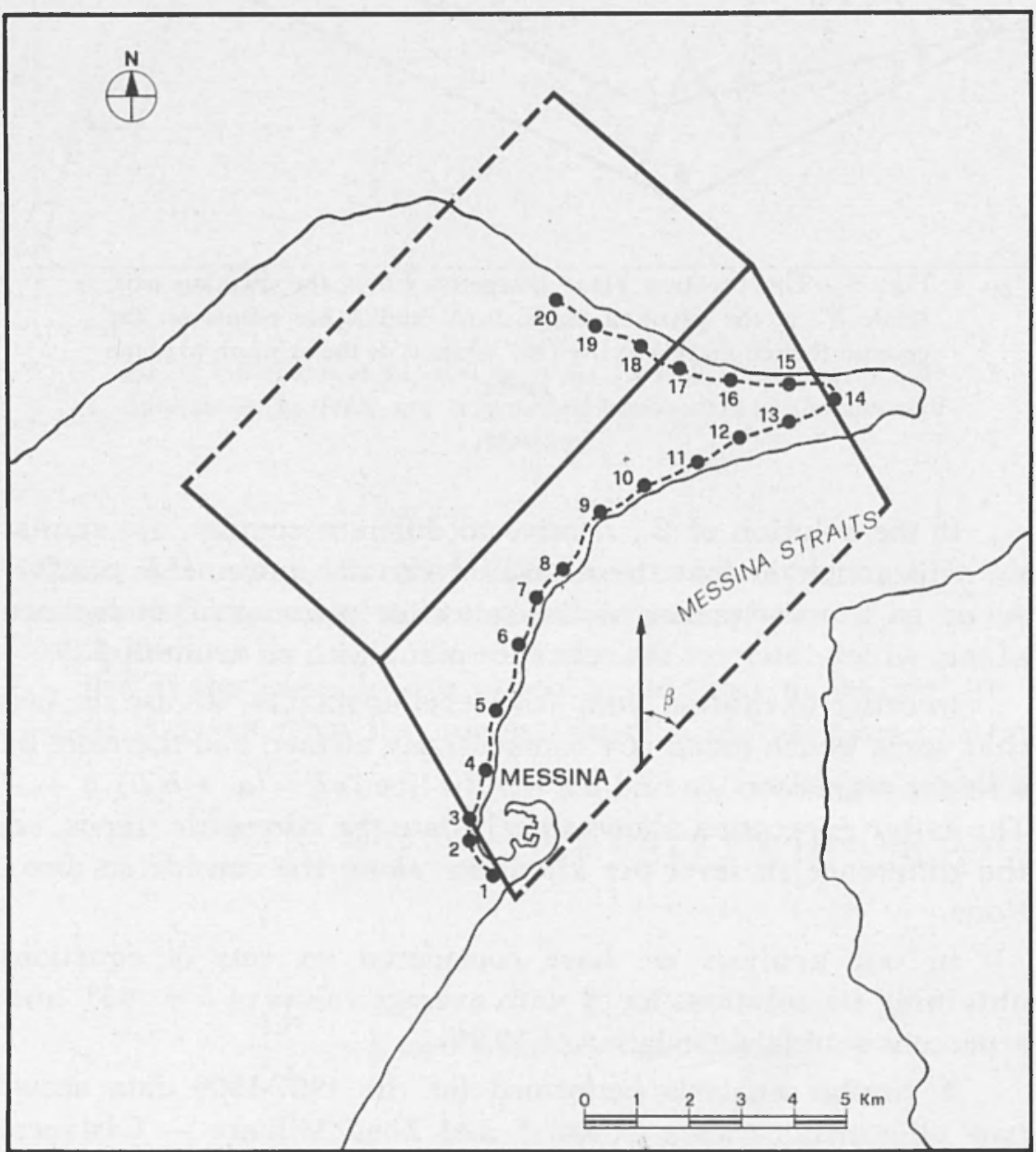

Fig. 4 - The two pivoting planes. Both show a sinking rotation of their ends. The numbers indicate the position of the bench-marks as indicated in table $\mathbf{I}$. 
rotations are found. The first, which has been already described is on the east side of the axis and shows a sinking (clockwise) rotation (see fig. 4); the second one is found on the left of the axis, and, although the evidence is based on fewer points, shows as well a sinking (anticlockwise) rotation (see fig. 4).

\section{Conclusions.}

The analysis of the results of high precision levelling surveys performed by I.G.M. in 1967 and 1970 shows a trend of crustal vertical strains in agreement with the coseismic movements of the 1908 Messina earthquake. The movement found consists of two planes, one on the western and the other on the eastern side of a pivoting axis with azimuth strike $\beta=43^{\circ}$ to the the North; both the planes show a sinking rotation of their ends. On the other hand the sitting of the existing bench marks is mainly along the coastline and data on compact geological structures are sparse. This led the authors to start a high precision levelling survey (presently in progress) which, together with a trigonometric trilateration survey, will hopefully help to settle more precisely the nature and the entity of the movements in the whole Messina Straits area.

\section{ACKNOWLEDGEMENTS.}

We thank Prof. E. Boschi and Prof. P. Baldi for helpful advise, discussion and continuous support. 


\section{R EFERENCES}

Baratta M., 1901 - 1 terremoti d'Italia, Arnaldo Forni Editore.

Barberi F., GASParinI P., INNOCENTI F., VIlLARI L., 1973 - Volcanism of Southem Tyrrhenian Sea and its geodynamic implications. "J.G.R.", 78, pp. 5221-5232.

BotTARI A., 1971 - L'attività sismica nello Stretto di Messina nel ventennio 1950-1969. "Annali di Geofisica", 24, pp. 103-133.

Bottari A., Broccio F., Lo Giudice E., 1975 - Some seismological results and geostructural suggestions from a study of the Reggio Calabria earthquake of 16 January, 1975. "Annali di Geofisica", 28, pp. 219-239.

BotTARI A. and Lo Giudice E., 1975b - Il terremoto di Reggio Calabria del 16 gennaio 1975. "Ann. Geofisic.", 28, 2-3.

Caputo M., Panza G.F., PostPischl D., 1970 - Deep structure of the Mediterranean basin. "J.G.R.", 75, pp. 4919-4923.

Caputo M., Folloni G., Pieri L., Unguendoli M., 1974 - Geodimetric control across the Strait of Messina. "G.J.R. Astr. Soc", 38, pp. 1-8.

Cortese E., $18 \AA_{2}$ - Sulla formazione dello Stretto di Messina. "Boll. Reg. Com. Ital.", 3, pp. 4-29.

CORTESE E., 1895 - Geotettonica e sismologia della descrizione geologica della Calabria "Mem. Descr. Carta Geol. d'Italia", 9, pp. 30-62.

FinetTi I., Morelli C., 1972 - Wide scale digital seismic exploration of the Mediterranean Sea. "Boll. Geofis. Teor. Appl.", 14, pp. 291-342.

Glangeaud L., 1952a - Les phénoménes géophysiques et l'évolution de la Méditerranée occidentale. "Ann. Geophys.", 8, 1, pp. 112-132.

Glangeaud L., 1952b - Interprétation téctonophysique des caractères structuraux et paléogéographiques de la Méditerranée occidentale. "Bull. Soc. Géol. France", 6, 1, pp. 735-762.

Istituto Geografico Militare, 1972 - Controllo Geodetico Periodico dello Stretto di Messina "I.G.M.", Firenze.

Limanowski M., 1913 - Die grosse Kalabrische Decke. "Bull. Int, Acad. Sc. Cracovie", Cl Sc. Math. Nat., S.A., 6, A, pp. 370-385.

LOPERFIDO A., 1909 - Livellazione geometrica di precisione. Relazione della Commissione Reale, Roma, Allegato D, pp. 146-152.

Ogniben L., 1960 - Nota illustrativa dello schema geologico della Sicilia nordorientale. "Riv. Miner. Sicil. Palermo", 11, pp. 183-212.

Ogniben L., 1966 - Lineamenti idrogeologici dell'Etna. "Riv. Miner. Sicil. Palermo", 17, pp. 151-174. 
Ogniben L., 1971 - Tettonica della Sicilia e della Calabria. "Boll. Acc. Gioenia Sc. Nat.", Catania, ser. IV, 11, pp. 14-26.

OGNIBEN L., 1973 - Schema geologico della Calabria in base ai dati odiemi. "Geologia Romana", 12, pp. 243-585.

Ritsema A.R., 1971 - Notes on plate tectonics and movements in the Mediterranean region. "Proc. Eur. Seism. Comm.", Luxemburg.

ScHICK R., 1977 - Studio sismotettonico del terremoto di Messina dell'anno 1908. "Annuario Geologico", E 11, pp. 3-74.

Trevisan L., 1954 - Les mouvéments tectoniques récent en Sicile. Hypothéses et problèmes, "Geol. Rend.", 43, pp. 207-221.

Vecchia O., 1956 - La Sicilia e le aree circostanti, lineamenti geofisici $e$ geologia profonda. "Boll. Soc. Geol. Ital", 75, pp. 61-87. 